\title{
Associations of air pollution concentrations and energy production dynamics in Pakistan during lockdown
}

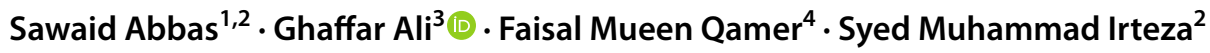

Received: 11 June 2021 / Accepted: 8 December 2021 / Published online: 19 January 2022

(c) The Author(s), under exclusive licence to Springer-Verlag GmbH Germany, part of Springer Nature 2021

\begin{abstract}
This study investigated atmospheric changes that occurred due to changes in energy production and consumption before and during the COVID-19 pandemic. We analyzed nitrogen dioxide $\left(\mathrm{NO}_{2}\right)$, aerosol optical depth (AOD), and rainfall patterns to understand the associated changes in emissions, especially from the power generation sector, before (2018 and 2019) and during the lockdown of 2020 across Pakistan. Regression analysis indicated a strong association between energy production by thermal power plants and tropospheric $\mathrm{NO}_{2}$ concentrations. Notably, a comparison between emission sources showed that the $\mathrm{NO}_{2}$ emissions from a single thermal power plant were equivalent to the emissions from a major city. During the lockdown, we observed a $40 \%$ reduction in $\mathrm{NO}_{2}$ emissions from coal-based power plants and a $30 \%$ reduction in mega- and major cities compared to the same retro in 2019. We also observed an approximate $25 \%$ decrease in AOD in the industrial and energy sectors, although no major decrease was obvious in the cities. Rainfall contributed to reducing the $\mathrm{NO}_{2}$ concentrations during monsoon season across all power plants in Pakistan, whereas it did not significantly correlate with AOD. The findings highlight the need for appropriate management and use of renewable energy in the industrial sector and transportation systems. Future research could estimate the environmental and public health costs linked to pollution originating from thermal energy production and poor transportation infrastructure.
\end{abstract}

Keywords Aerosol optical depth $\cdot$ Air quality $\cdot$ COVID-19 $\cdot$ Energy production $\cdot$ Energy policy $\cdot$ Remote sensing $\cdot \mathrm{NO}_{2}$

\begin{tabular}{ll}
\multicolumn{2}{l}{ Abbreviations } \\
AOD & Aerosol optical depth \\
ADB & Asian Development Bank \\
COVID-19 & Coronavirus disease \\
GDP & Gross domestic product \\
GEE & Google Earth Engine \\
IMF & International Monetary Fund \\
LST & Land surface temperature
\end{tabular}

Responsible editor: Roula Inglesi-Lotz

Ghaffar Ali

ghafar.gs@gmail.com

1 Department of Land Surveying and Geoinformatics, The Hong Kong Polytechnic University, Hong Kong, Hong Kong

2 Remote Sensing, GIS and Climatic Research Lab (RSGCRL), National Center of GIS and Space Applications, University of the Punjab, Lahore, Pakistan

3 College of Management, Shenzhen University, Nanhai Ave 3688, Shenzhen 518060, China

4 International Center for Integrated Mountain Development (ICIMOD), Kathmandu 44700, Nepal

\begin{tabular}{|c|c|}
\hline MW & Megawatt \\
\hline MT & Million tons \\
\hline MODIS & Moderate Resolution Imaging \\
\hline & Spectroradiometer \\
\hline MAIAC & $\begin{array}{l}\text { Multi-Angle Implementation of Atmos- } \\
\text { pheric Correction }\end{array}$ \\
\hline $\mathrm{NO}_{2}$ & Nitrogen dioxide \\
\hline $\mathrm{PM}_{2,5} / \mathrm{PM}_{10}$ & Particulate matter \\
\hline RLNG & Re-gassified liquified natural gas \\
\hline RFO & Residual fuel oil \\
\hline $\mathrm{SO}_{2}$ & Sulfur dioxide \\
\hline TROPOMI & TROPOspheric Monitoring Instrument \\
\hline VOC & Volatile organic carbon \\
\hline WHO & World Health Organization \\
\hline
\end{tabular}

\section{Introduction}

The global spread of "coronavirus disease 2019" (COVID19 ) is a serious threat to public health (WHO 2020). The COVID-19 pandemic is the most acute health crisis of our time and the greatest challenge that humanity has faced in 
the post-World War II era. Moreover, the consequent lockdowns imposed across the world as a measure to contain the spread of the virus are impeding global economic growth (Maliszewska et al. 2020). Since its emergence in December 2019, COVID-19 rapidly spread around the world, leading the World Health Organization (WHO) to declare it a pandemic on March 11, 2020. As a measure to retard its spread, almost two billion people around the world were placed under partial or complete lockdowns, significantly reducing the volume of transportation and bringing industrial activities to a near-complete halt (Ali et al. 2021a). The lockdowns have undoubtedly caused both human and financial losses, while numerous challenges still lie ahead. However, the crisis has also reminded us of the need to build a safer and more resilient world that can respond to any future biological crisis (ADB 2020). Energy production, especially from thermal power plants, and its consumption directly or indirectly influence the environmental equilibrium.

AOD is a measure of atmospheric aerosols originating from smoke, sand, and dust, as well as industrial pollution and vehicular emissions. It indicates how much sunlight is blocked by aerosol particles. An increased AOD can affect the net radiation balance of Earth and is dangerous for human health. Satellite-derived AOD has been used to collect information on particulate matter $\left(\mathrm{PM}_{2.5}\right.$ and $\left.\mathrm{PM}_{10}\right)$ (Kumar et al. 2007; Stirnberg et al. 2018). Atmospheric pollutants such as $\mathrm{NO}_{2}$ and $\mathrm{PM}_{2.5}$ have been associated with high human mortality rates. Only in 2018, an estimated 4.5 million people died because of atmospheric pollution caused by fossil fuel burning. $\mathrm{PM}_{2.5}$ pollution causes an estimated 3 million deaths, while $\mathrm{NO}_{2}$ pollution is responsible for 500,000 deaths. Atmospheric pollution has also resulted in an increase in asthma cases in children. Exposure to $\mathrm{PM}_{2.5}$ pollution causes 7.7 million asthma cases worldwide (Myllyvirta 2020). As per the guidelines of the World Bank, the concentration of all sizes of PM should not exceed $50 \mathrm{mg} /$ $\mathrm{Nm}^{3}$ (World Bank 1998).

Several studies have shown that air pollutants significantly decreased during strict lockdowns in different countries (Ali et al. 2021b). AOD in regions where blast furnaces were allowed to keep operating increased compared to a $30 \%$ reduction in atmospheric $\mathrm{NO}_{2}$ due to the closure of fossil fuel power plants, such as in eastern China (Filonchyk et al. 2020). Mobility restrictions also significantly reduced atmospheric pollutant $\left(\mathrm{NO}_{2}, \mathrm{PM}_{2.5}\right.$, and $\left.\mathrm{PM}_{10}\right)$ concentrations in 44 cities of China (Bao and Zhang 2020). Likewise, significant decreases in AOD were observed throughout India during a strict lockdown that started in March 2020 (Mahato et al. 2020). In Delhi, a 60\% reduction in $\mathrm{PM}_{10}$ and a $39 \%$ reduction in $\mathrm{PM}_{2.5}$ were observed (Gautam 2020). In Sao Paolo, Brazil, a $29.8 \%$ reduction in $\mathrm{PM}_{2.5}$ and a $54.3 \%$ reduction in $\mathrm{NO}_{2}$ compared to a five-year monthly mean were recorded due to a partial lockdown (Yuri et al. 2020). In
Tehran, Iran, an overall increase in AOD and a reduction in $\mathrm{NO}_{2}$ were observed between February and April 2020. $\mathrm{PM}_{2.5}$ pollution increased by $2-50 \%$, whereas $\mathrm{PM}_{10}$ decreased by $1.4-30 \%$, and $\mathrm{NO}_{2}$ decreased by $1-33 \%$. The increase in $\mathrm{PM}_{2.5}$ concentration was mostly attributed to the continuation of fossil fuel power plant operations near observed sites and increased sand and dust storms. It is worth noting that due to the continuation of power plant operations, even though a reduction in $\mathrm{NO}_{2}$ and $\mathrm{PM}_{10}$ was observed, their levels were still high compared to the recommended values (Broomandi et al. 2020).

Environmental risks to human health as well as to economies worldwide are severely caused by air pollution (Sánchez-Triana et al. 2014). In Pakistan, the total energy supply amounts to nearly $70 \mathrm{Mt}$ of oil equivalent, with oil and gas accounting for 80\% (HDIP 2019). Moreover, carbon emissions from energy consumption in Pakistan were almost 198.3 Mt in 2019, growing at an average annual rate of 3.34\% in 2019 (HDIP 2019). Greenhouse gas emissions in Pakistan are dominated by carbon dioxide $\left(\mathrm{CO}_{2}\right)$, which accounts for $54 \%$ (158.1 Mt), and methane $\left(\mathrm{CH}_{4}\right)$, which accounts for about 36\% (111.6 Mt), followed by $\mathrm{NO}_{2}$, accounting for about $9 \%(27.9 \mathrm{Mt})$, carbon monoxide (CO), accounting for $0.75 \%$ (2.17 Mt), and volatile organic carbon, accounting for $0.3 \%$ (0.93 Mt) (Rauf et al. 2015). Overall $\mathrm{CO}_{2}$ emissions have been predicted to reach $250 \mathrm{Mt}$ by 2020 (yet to be measured), and this trend may continue if sources of renewable energy are not adopted (Bhutto et al. 2013). Table 1 presents statistics on the total energy supply in Pakistan in the last four decades. Aside from imported energy, two-thirds of Pakistan's total energy requirements are met by energy produced locally by thermal and hydroelectric power plants (Mirjat et al. 2017; SBP 2018; Shahzada et al. 2018). Governmental policies on energy production and imports indicate that the development of power production infrastructure has become a priority over the last decade (Anwar 2016). Although Pakistan has been able to manage its energy shortages, reducing the share of imported energy and increasing clean energy production remain challenging.

This study conducted a remote sensing-based assessment of changes in $\mathrm{NO}_{2}$ and $\mathrm{AOD}$ emissions before and during the COVID-19 lockdown along with the contribution of rainfall across Pakistan. We considered energy production in coal

Table 1 Total primary energy supply by source for Pakistan (ktoe)

\begin{tabular}{llllll}
\hline Year & Coal & Natural gas & Nuclear & Hydro & Oil \\
\hline 1990 & 2002 & 10080 & 76 & 1455 & 10682 \\
2000 & 1862 & 16668 & 520 & 1478 & 19011 \\
2010 & 4185 & 27002 & 891 & 2735 & 20212 \\
2019 & 10990 & 27036 & 2674 & 2611 & 28735 \\
\hline
\end{tabular}

Source: HDIP 2019 
and gas power plants; major cities and megacities; AOD, $\mathrm{NO}_{2}$, and rainfall; and COVID-19 policy analysis. To our knowledge, no such study has previously been conducted in Pakistan. Our findings are therefore timely and will contribute to our understanding of the environmental dynamics in Pakistan and the measures needed to minimize their adverse impacts.

\section{Materials and methods}

\section{Study area and selection of sites}

We selected 20 locations across Pakistan for this study. The locations were selected based on the spatial intersection of urban clusters; $\mathrm{NO}_{2}$ emission hotspots derived from average conditions during 2018, 2019, and 2020; and major emission sources (Fig. 1). The identified locations can be categorized into five emission sources: megacities (such as Karachi, Lahore, Faisalabad, and Rawalpindi-Islamabad), major cities (such as Multan, Peshawar, Hyderabad, and Quetta), industrial areas (such as Taxila and Sadiqabad), gas fields (such as Sui, Daharki, and Ghotki), power plants (Kashmore, Kotaddu, and Sahiwal), and cement factories (such as Pezu, Kalabagh, Khewra, and Ameer). Air pollution conditions were assessed for all 20 sites by measuring $\mathrm{NO}_{2}$ and AOD levels. Three major thermal power plants were selected: Sahiwal coal power plant (installed capacity of 1,320 MW), Kotaddu regasified liquefied natural gas (RLNG) power plant (installed capacity of 1,600 MW), and Kashmore (Guddu) natural gas power plant (installed capacity of 2,402 MW).

\section{Data collection and pre-processing}

The AOD, $\mathrm{NO}_{2}$, and rainfall data sets were acquired and preprocessed using the cloud computing platform of the Google Earth Engine (GEE). The GEE provides the $\mathrm{NO}_{2}$ measurements, concentration in the tropospheric column, recorded by the TROPOMI sensor of the Sentinel-5P (Omrani et al. 2020). The dataset set is delivered at the $1 \mathrm{~km}$ spatial resolution with the very strict quality control by removing bad quality pixels of quality assurance (QA) less than $75 \%$. Also, to ensure minimum contamination of cloudy pixels, only the pixels with cloud probability of less than $20 \%$ were retained for subsequent processing. The measurement units of the $\mathrm{NO}_{2}$ concentration were converted to $\mu$ moles $/ \mathrm{m}^{2}$ to facilitate analysis and data visualization.

Likewise, GEE provides the "Moderate Resolution Imaging Spectroradiometer (MODIS)" product (MCD19A2-V6), which is based on daily observations from the "Terra" and "Aqua" satellites. The daily AOD measurements are derived by applying the MAIAC, "Multi-Angle Implementation of Atmospheric Correction," algorithm at a spatial resolution of $1 \mathrm{~km}$ (Levy et al. 2010). For this study, we used the monthly average of the daily AOD at $550 \mathrm{~nm}$, and the data
Fig. 1. Locations of the selected sites overlaid on an average tropospheric $\mathrm{NO}_{2}$ concentration map of Pakistan

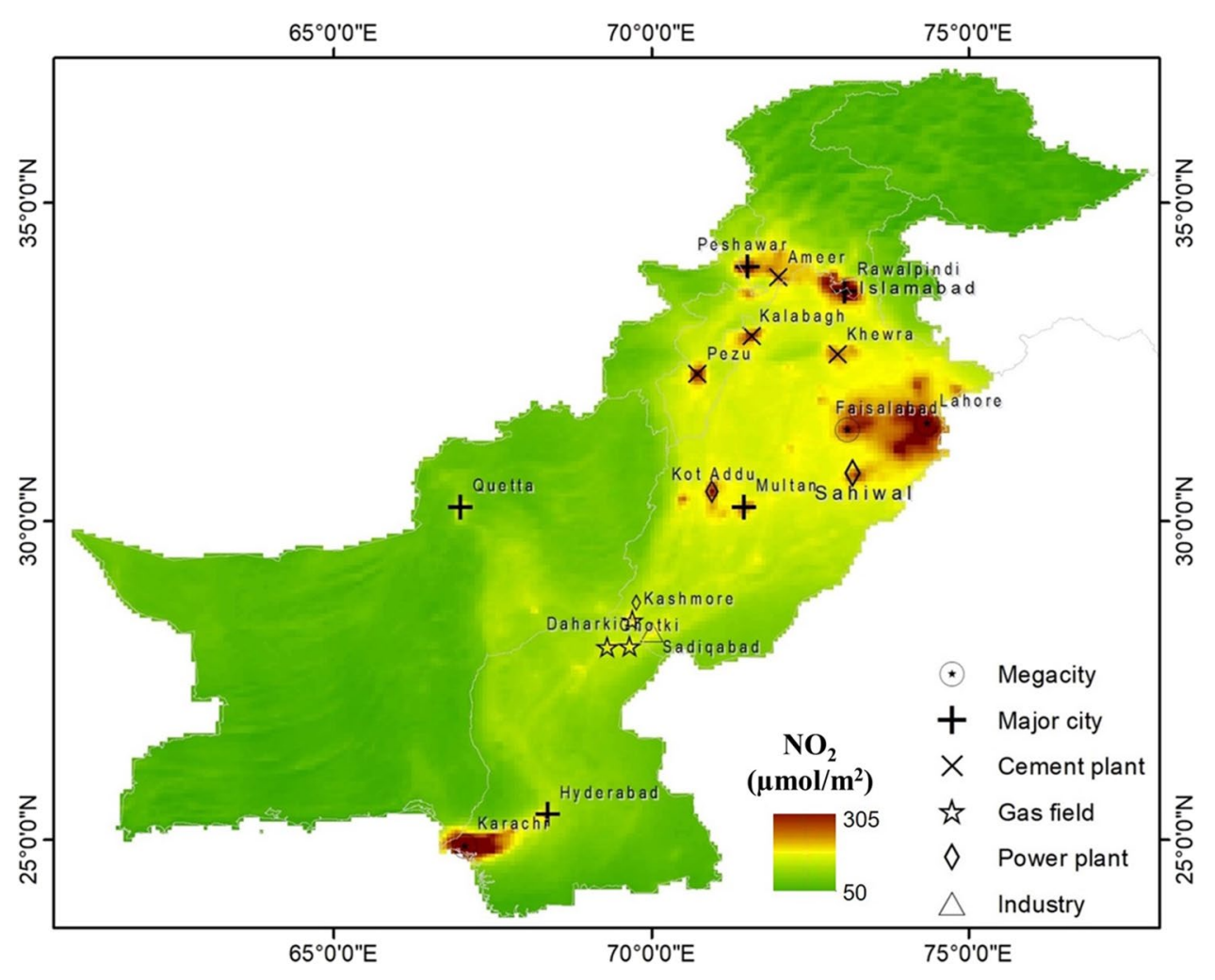


was masked using quality tags to ensure high-quality pixels only.

Rainfall is an important contributor factor while investigating temporal patterns of air quality. Therefore, the corresponding rainfall measurements were obtained from the Climate Hazards Group Infrared Precipitation with Station (CHIRPS) rainfall product (Rowland et al. 2015). It is an integrated product derived by combining in situ rainfall measurements and satellite observations. The daily CHIRPS rainfall estimates have been ingested in the GEE with a native spatial resolution of $5 \mathrm{~km}$. In this study, we extracted monthly accumulative rainfall over the 20 sites under investigation. Besides, station-based measurements of rainfall and temperature were obtained from the Pakistan Meteorological Department.

\section{Data analysis}

Monthly estimates of AOD, $\mathrm{NO}_{2}$, and rainfall were examined to determine the association of power consumption and its associated environmental impacts over 22 months from July 2018 to May 2020. The analysis was performed over representative sites of the four major sectors of power consumption including megacities, major cities, cement plants, and industrial regions. The "non-parametric Wilcoxon test" was applied to determine the sites with significant changes in the air pollutants. Also, an association of energy production and emissions was investigated by developing linear regression models to ascertain the environmental impacts of energy generated through coal, RNLG, and gas-fueled power plants in Sahiwal, Kotaddu, and Kashmore. A time series analysis was performed to quantify the changes in the air pollutants by comparing the measurements during the normal year of 2019 with the lockdown period (March to May) in 2020. A territory-wide lockdown was enforced in Pakistan from March 25, 2020, to April 15. The lockdown enforcement was partially relaxed, and the economic activities started to resume by the end of April. We divided the analytical framework into three periods: summer, spring, rainy, and winter seasons of (1) 2018 and (2) 2019 and (3) the lockdown period of 2020. A linear trend analysis of the time sequence data was performed by applying the "loess" fitting to identify significantly different temporal patterns during the lockdown period of 2019 and 2020.

\section{Results and discussion}

This section is divided into three main parts: a pre-lockdown, a during/after lockdown part, and energy, environment, and lockdown nexus. Table 2 presents a summary of the $\mathrm{NO}_{2}$ and AOD statistics by emission source (megacities,
Table 2 Energy generation mix for Pakistan (MW)

\begin{tabular}{lll}
\hline Type & $\begin{array}{l}\text { Generation } \\
\text { 2018(MW) }\end{array}$ & $\%$ \\
\hline Gas & 4,994 & 13 \\
RLNG & 7,275 & 22 \\
Coal & 2,754 & 8 \\
RFO & 5,887 & 18 \\
Bagasse & 306 & 1 \\
Solar & 400 & 1 \\
Wind & 1,185 & 4 \\
Nuclear & 1,345 & 4 \\
Hydro & 973 & 29 \\
\hline
\end{tabular}

Source: HDIP 2019

major cities, industrial areas, gas fields, power plants, and cement factories).

\section{Pre-lockdown period}

Energy produced by a thermal power plant goes through several stages. First, fuel is burned to convert water in boilers into high-pressure steam, which is then used to run turbines to produce electricity. Coal-fired power plants have an overall efficiency of $40 \%$ due to losses in various stages. This means that $60 \%$ is pollution, consisting of $\mathrm{NO}_{\mathrm{x}}, \mathrm{CO}_{2}$, fly ash, and PM. Coal properties, such as nitrogen content, nitrogen partitioning, heating value, and volatile release, as well as boiler design and operation, influence $\mathrm{NO}_{\mathrm{x}}$ emissions from coal-fired power plants. During the coal combustion process, $\mathrm{NO}_{2}$ and nitrous oxide $\left(\mathrm{N}_{2} \mathrm{O}\right)$ account for just $5 \%$ of the total $\mathrm{NO}_{\mathrm{x}}$ emissions, whereas $\mathrm{NO}$ accounts for $95 \%$. This is because oxygen levels are too low for NO to oxidize into $\mathrm{NO}_{2}$. At the end of 2019, Pakistan's share of coal reserves was $0.3 \%$, its total coal production accounted for $0.1 \%$ of the global production, and its coal consumption accounted for $0.3 \%$. An increase in the demand for electricity due to rapid industrialization and ever-increasing urbanization has forced nations to increase their energy production using fossil fuels, thus increasing greenhouse gas emissions (such as $\mathrm{NO}_{2}$ ). Pakistan's energy production increased from $1,116 \mathrm{GWh}$ in October 2018 to 2,357 GWh in October 2019.

Pre-lockdown period is 2018 and 2019. Pakistan meets more than $60 \%$ of its energy requirements from fossil fuels, that is, oil, natural gas, and coal (Table 2). The remaining $40 \%$ is met by hydroelectric, nuclear, wind, and solar power (Table 2). In terms of energy demand, June is the peak period, whereas January and February are characterized by the lowest energy needs. Most of the winter energy demand is met through thermal energy generation, while the high energy demand in summer is met through an increase in hydroelectric energy generation. Energy production by the Sahiwal coal power plant and the 
Guddu natural gas power plant remained stable throughout 2018-2019, whereas Kotaddu had sharp monthly fluctuations, which can be attributed to challenges related to the payment mechanism (Table 3, Fig. 2).

Figure 3 a shows the correlation between energy production and $\mathrm{NO}_{2}$. The increasing trend of the regression line indicates a positive and significant association between energy production and $\mathrm{NO}_{2}$. An increase in one unit of energy production led to a 0.05141 unit increase in $\mathrm{NO}_{2}$. An $R^{2}$ of $46 \%$ indicated that $46 \%$ of the model was explained by energy production. Figure 3 (right) also shows a positive and significant association between energy production and $\mathrm{NO}_{2}$. A one-unit increase in energy production led to a 0.03540 unit increase in $\mathrm{NO}_{2}$. A lower $R^{2}$ of $22 \%$ indicated that $22 \%$ of the model was explained by energy production. Since rainfall contributes to diminishing the concentration of air pollutants, the rainy period was excluded from the calculation of the energy production-pollution correlation. The $\mathrm{NO}_{2}$ concentration peaked in winter and fell in summer due to increased rainfall during July and August. An unusual AOD increase in July 2018/2019 was observed countrywide and across emission source categories (Fig. 4, Table 3), which previous studies have attributed to dust storms during this period (Colbeck et al. 2010; Shahid et al. 2015]. Further estimations of average energy, $\mathrm{NO}_{2}, \mathrm{AOD}$, and rainfall are shown in Table 3 and Fig. 4.

In winter, high concentrations of atmospheric pollutants such as $\mathrm{NO}_{2}, \mathrm{SO}_{2}, \mathrm{CO}_{2}$, and $\mathrm{PM}_{2.5}$ are generally observed, whereas $\mathrm{O}_{3}$ decreases. Ozone concentrations depend on the amounts of sunlight and heat. More ozone formation occurs on sunny than on cloudy or relatively cold days. Thermal inversion occurring from December to March lowers the height of particles, resulting in increased pollution at lower levels. During winter, these suspended particles form fog at the ground level. More pollutants are observed under stable weather and sunny conditions in this region (Dantas et al. 2020; Sami et al. 2006). In summer, as hot air rises due to high temperatures, which exceed $45^{\circ} \mathrm{C}$, dust particles rise to form dust clouds. This creates haze over the entire southern Punjab and most of the upper region of Sindh. Further, dust storms originating from nearby deserts reduce visibility in the entire region.

\section{Period during/after the lockdown}

The Pakistan government imposed a lockdown after an increase in COVID-19 cases, which started in Sindh on March 23, 2020, and was followed by lockdowns in several other major cities. Severe restrictions, such as social

Table 3 Energy, $\mathrm{NO}_{2}$, AOD, and rainfall estimations from 2018 to 2020

\begin{tabular}{|c|c|c|c|c|c|c|c|c|c|c|c|c|}
\hline \multirow[b]{2}{*}{$\begin{array}{l}\text { Date } \\
\text { mmm-yy }\end{array}$} & \multicolumn{4}{|c|}{ Kashmore/Guddu power plant } & \multicolumn{4}{|c|}{ Kotaddu coal and gas power plant } & \multicolumn{4}{|c|}{ Sahiwal power plant } \\
\hline & $\begin{array}{l}\text { Energy } \\
\mathrm{kWh} 10^{6}\end{array}$ & $\begin{array}{l}\mathrm{NO}_{2} \\
\mu_{\text {molem }}^{-2}\end{array}$ & AOD & $\begin{array}{l}\text { Rainfall } \\
\mathrm{mm}\end{array}$ & $\begin{array}{l}\text { Energy } \\
\mathrm{kWh} 10^{6}\end{array}$ & $\begin{array}{l}\mathrm{NO}_{2} \\
\mu_{\text {molem }}{ }^{-2}\end{array}$ & AOD & $\begin{array}{l}\text { Rainfall } \\
\text { mm }\end{array}$ & $\begin{array}{l}\text { Energy } \\
\mathrm{kWh} 10^{6}\end{array}$ & $\begin{array}{l}\mathrm{NO}_{2} \\
\mu_{\text {molem }}{ }^{-2}\end{array}$ & AOD & $\begin{array}{l}\text { Rainfall } \\
\mathrm{mm}\end{array}$ \\
\hline Jul-18 & 805.46 & 41.768 & 1.168 & 14.941 & 780.44 & 67.947 & 0.999 & 36.149 & 891.32 & 59.055 & 0.778 & 120.489 \\
\hline Aug-18 & 838.66 & 37.768 & 1.111 & 10.349 & 811.31 & 59.545 & 0.832 & 14.837 & 815.05 & 51.289 & 0.741 & 37.849 \\
\hline Sep-18 & 870.28 & 46.143 & 0.595 & 0 & 473.24 & 54.092 & 0.415 & 11.958 & 454.97 & 53.581 & 0.269 & 15.622 \\
\hline Oct-18 & 861.02 & 73.226 & 0.41 & 0 & 340.66 & 58.321 & 0.509 & 0.694 & 526.44 & 65.541 & 0.707 & $\mathbf{0}$ \\
\hline Nov-18 & 805.10 & 55.245 & 0.752 & 1.811 & & 38.185 & 0.834 & 1.215 & 538.94 & 62.135 & 0.775 & 3.741 \\
\hline Dec-18 & 705.02 & 58.913 & 0.531 & 2.181 & 209.99 & 66.925 & 0.611 & 4.276 & 742.75 & 79.43 & 0.59 & 2.433 \\
\hline Jan-19 & 721.85 & 47.812 & 0.622 & 27.457 & 344.50 & 77.873 & 0.61 & 15.43 & 710.74 & 58.56 & 0.587 & 19.988 \\
\hline Feb-19 & 752.36 & 60.97 & 0.39 & 39.329 & 28.89 & 33.951 & 0.315 & 17.13 & 517.07 & 59.702 & 0.379 & 16.358 \\
\hline Mar-19 & 788.34 & 60.674 & 0.422 & 26.469 & 11.26 & 28.339 & 0.312 & 40.779 & 761.71 & 56.168 & 0.297 & 22.564 \\
\hline Apr-19 & 722.95 & 65.956 & 0.387 & 12.318 & 595.05 & 60.746 & 0.355 & 51.907 & 743.66 & 64.134 & 0.344 & 28.463 \\
\hline May-19 & 806.54 & 69.276 & 0.636 & 8.069 & 650.16 & 64.702 & 0.363 & 19.593 & 760.70 & 71.462 & 0.38 & 20.524 \\
\hline Jun-19 & 706.73 & 45.148 & 1.085 & 1.146 & 61.74 & 59.774 & 0.557 & 25.127 & 756.71 & 68.348 & 0.578 & 19.627 \\
\hline Jul-19 & 603.51 & 40.997 & 1.202 & 26.455 & 803.09 & 56.689 & 1.228 & 28.186 & 733.76 & 60.738 & 1.009 & 138.707 \\
\hline Aug-19 & 607.96 & 39.013 & 0.735 & 23.876 & 778.48 & 53.107 & 0.696 & 79.287 & 508.25 & 47.609 & 0.711 & 51.056 \\
\hline Sep-19 & 590.90 & 35.95 & 0.522 & 6.821 & 519.52 & 46.45 & 0.457 & 23.308 & 411.88 & 41.638 & 0.499 & 36.505 \\
\hline Oct-19 & 606.30 & 42.198 & 0.452 & 5.465 & 371.64 & 31.772 & 0.409 & 11.057 & 425.90 & 62.69 & 0.508 & 9.611 \\
\hline Nov-19 & 300.79 & 39.052 & 0.487 & 2.573 & & 31.882 & 0.229 & 4.002 & 448.39 & 68.569 & 0.204 & 7.822 \\
\hline Dec-19 & 472.82 & 38.491 & 0.435 & 5.293 & & 45.477 & 0.261 & 7.867 & 621.60 & 57.015 & 0.167 & 8.707 \\
\hline Jan-20 & 824.13 & 43.237 & 0.454 & 14.984 & 329.32 & 52.103 & 0.533 & 21.375 & 818.07 & 58.518 & 0.623 & 41.21 \\
\hline Avg & 704.77 & 49.57 & 0.65 & 12.08 & 444.33 & 51.99 & 0.55 & 21.80 & 641.47 & 60.33 & 0.53 & 31.65 \\
\hline
\end{tabular}


a) Sahiwal Coal Power Plant

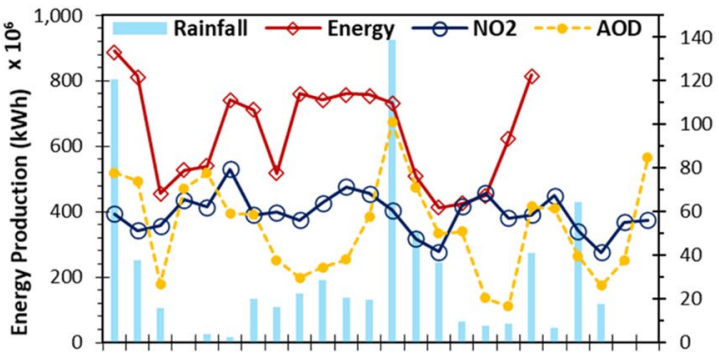

b) Kotaddu RLNG Power Plant

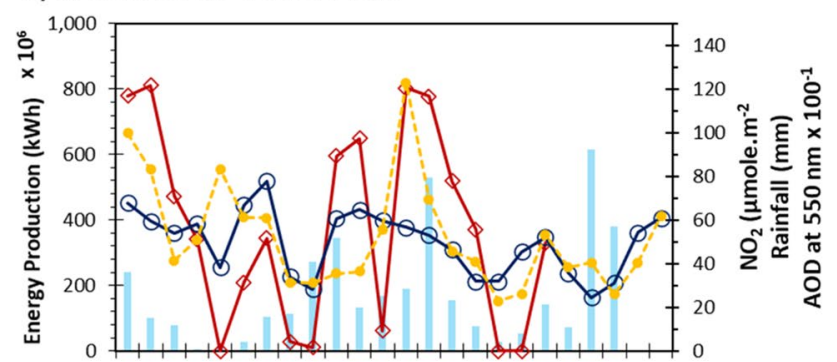

c) Kashmore (Guddu) Gas Power Plant

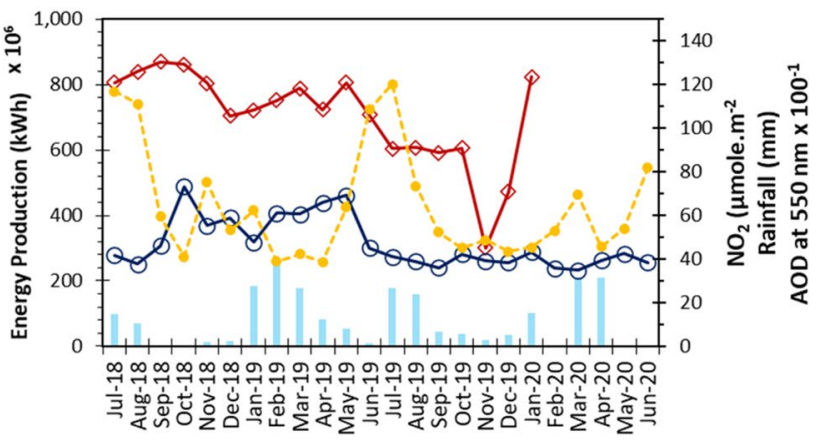

Fig. 2. Changes in AOD and $\mathrm{NO}_{2}$ in three power plants before and during the lockdown. a Sahiwal coal power plant. b Kotaddu RLNG power plant. c Kashmore (Guddu) gas power plant distancing measures, bans on intercity travels, restrictions in urban transportation, and closure of some COVID-19 hotspot industrial areas, during the first phase of the lockdown in March and April resulted in a significant reduction in atmospheric pollutants. To analyze $\mathrm{NO}_{2}$ levels before and during/after the lockdown, we used the $\mathrm{R}$ software package. Our results showed a significant decrease in $\mathrm{NO}_{2}$ emissions from all emission sources during the lockdown in 2020 compared to the same periods in 2018 and 2019 (Table 4). The highest decrease was observed over power plant regions (40\%), followed by megacities (37\%), major cities $(23.5 \%)$, industrial areas (19\%), and gas fields (8\%). Meanwhile, many other cities around the world also recorded reductions in $\mathrm{NO}_{2}$ levels due to lockdowns. In Rio de Janeiro, Brazil, $\mathrm{NO}_{2}$ levels dropped by 24.1-32.9\% (Zhao et al. 2020). A $24.67 \%$ reduction was recorded in 44 cities in China (Bao and Zhang 2020). An $18 \%$ reduction was noted in 88 cities across India (Sharma et al. 2020), while in Delhi, reduction reached 52.68\% (Mahato et al. 2020). In Salé, Morocco, $\mathrm{NO}_{2}$ levels fell by $96 \%$ due to reduced industrial activity (Otmani et al. 2020). In Barcelona, Spain, the reduction rate was $51 \%$ (Gupta et al. 2013).

Figure 5 depicts the $\mathrm{NO}_{2}$ concentration spread of tropospheric column for different cities of Pakistan such as industrial hubs of Pakistan (Peshawar, Lahore, Islamabad, and Rawalpindi). The in-depth analysis shows the decrement in the $\mathrm{NO}_{2}$ concentrations as the temperature increases. According to authors in Isaifan (2020), $\mathrm{NO}_{2}$ concentrations decrease with increasing temperatures. In the case of Pakistan analyzed through this analysis, $\mathrm{NO}_{2}$ concentrations are stable during the specified lockdown period (Fig. 6). During the lockdown period in 2020, a decrease in $\mathrm{NO}_{2}$ and temperature was pragmatic. It is notable that megacities, including Karachi, Lahore, Islamabad-Rawalpindi, and Faisalabad,
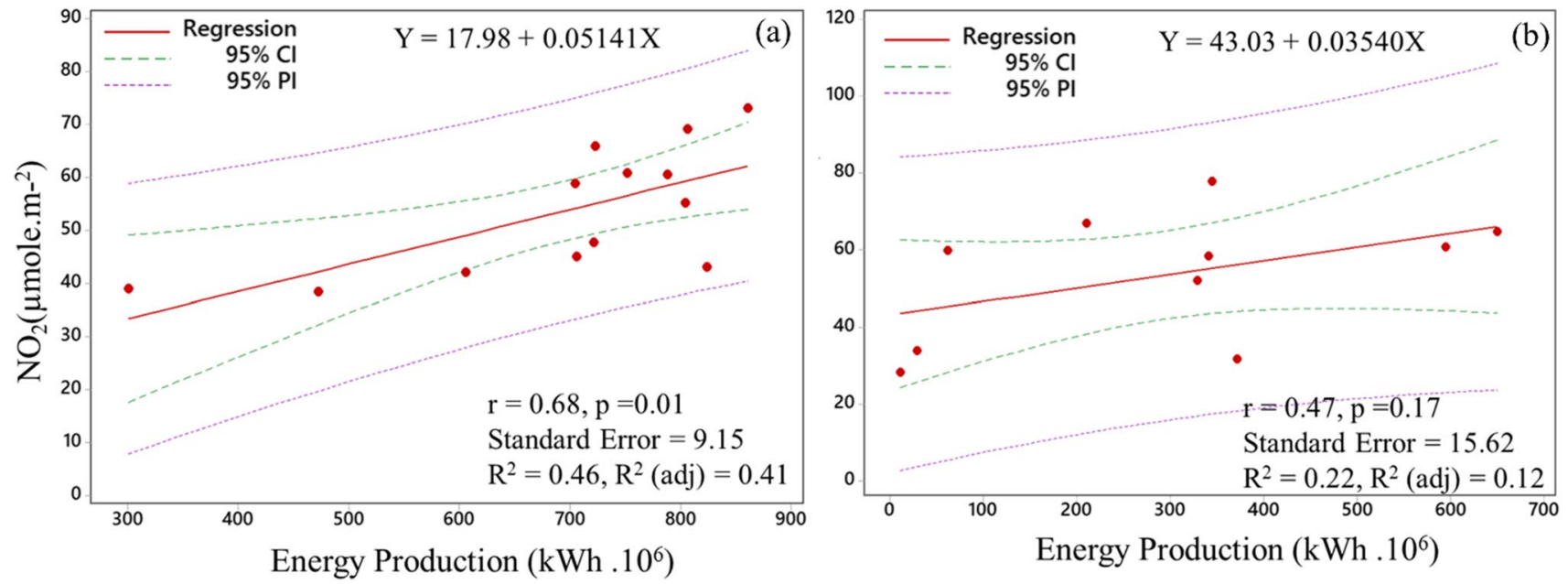

Fig. 3. Linear regression analysis of a energy production and tropospheric $\mathrm{NO}_{2}$ emissions over Guddu and $\mathbf{b}$ energy production and tropospheric $\mathrm{NO}_{2}$ emissions over Kotaddu 


\section{a) Megacities}

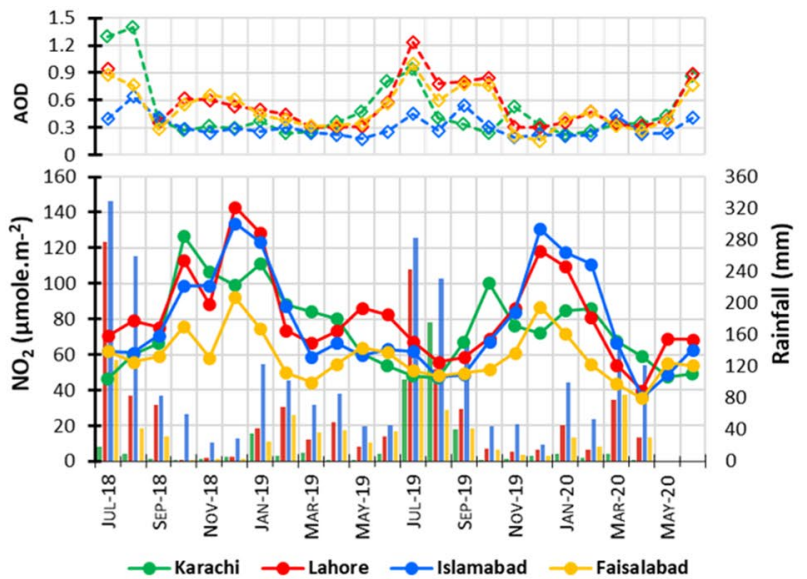

c) Cement Plants
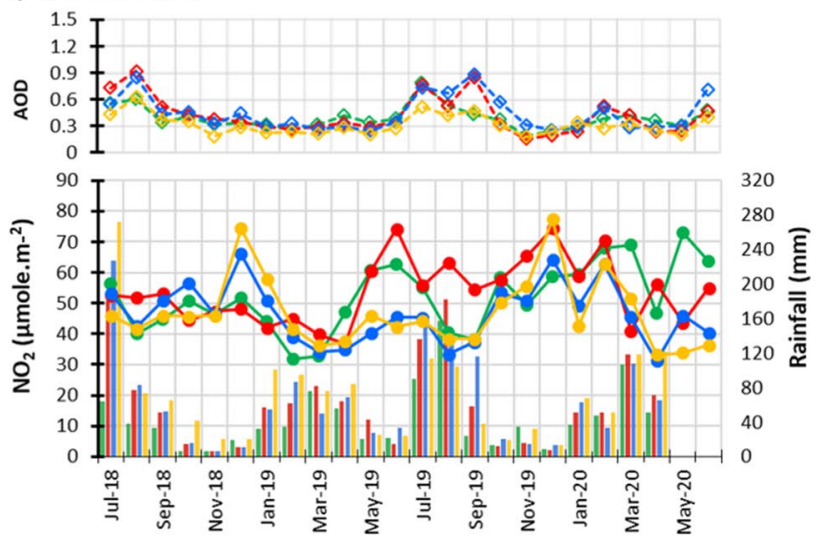

b) Majorcities
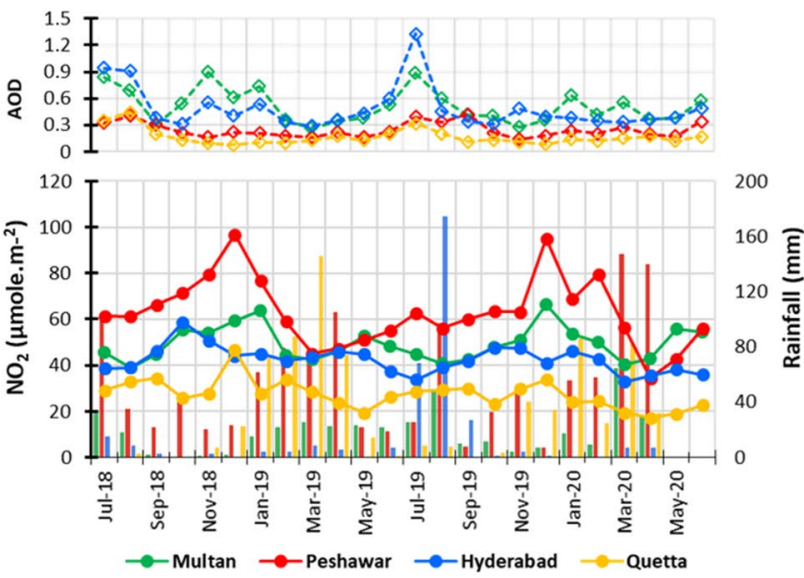

d) Gas fields / Industrial
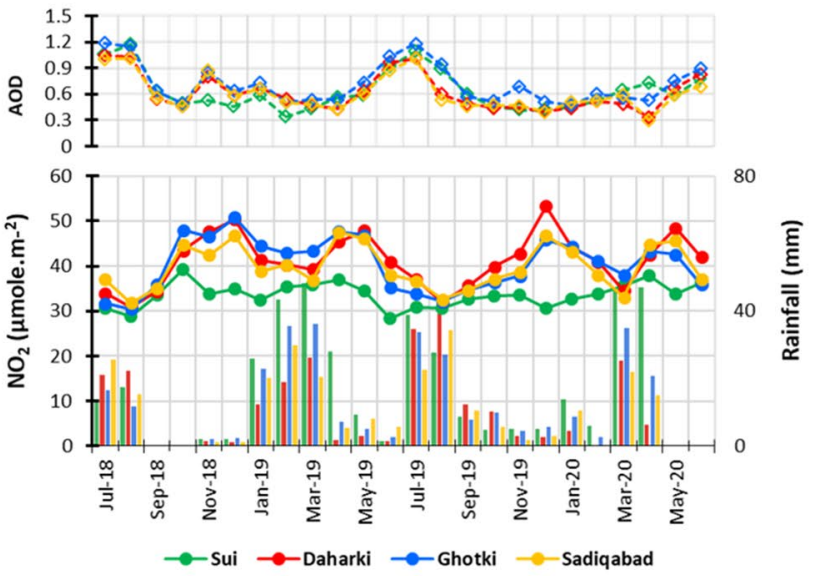

Fig. 4. Temporal patterns of tropospheric $\mathrm{NO}_{2}, \mathrm{AOD}$, and rainfall over different areas: a megacities, $\mathbf{b}$ major cities, $\mathbf{c}$ cement factories, and $\mathbf{d}$ gas fields and industrial areas

had $84.4 \mu \mathrm{mol} / \mathrm{m}^{2}, 70.3 \mu \mathrm{mol} / \mathrm{m}^{2}, 62.2 \mu \mathrm{mol} / \mathrm{m}^{2}, 50.1 \mu \mathrm{mol} /$ $\mathrm{m}^{2}$, and $\mathrm{NO}_{2}$ concentrations, respectively, averaging 66.7 $\mu \mathrm{mol} / \mathrm{m}^{2}$. Followed by coal-based power plants (average $\left.60.1 \mu \mathrm{mol} / \mathrm{m}^{2}\right)$ in Kashmore $\left(65.7 \mu \mathrm{mol} / \mathrm{m}^{2}\right)$, Sahiwal $(62.2$ $\left.\mu \mathrm{mol} / \mathrm{m}^{2}\right)$, and Kotaddu $\left(52.4 \mu \mathrm{mol} / \mathrm{m}^{2}\right)$, please refer to Table 4 and Fig. 6. It is evident to conclude that a reasonable amount of $\mathrm{NO}_{2}$ concentrations decreased during lockdown as compared to the previous years (2018-2019) in the same period. The following was the pattern of decrement in the emissions: regions with power plants showed almost $40 \%$ decrease, almost $37 \%$ by megacities, almost $23 \%$ by major cities, $19 \%$ by industrial regions, and lastly, $8 \%$ decrease in gas fields (see Table 4 for detail).

The highest AOD $\left(1.18 \mu \mathrm{g} / \mathrm{cm}^{2}\right)$ was observed in July 2018 , and the lowest $\left(0.16 \mu \mathrm{g} / \mathrm{cm}^{2}\right)$ was observed in December 2019 at the Guddu power plant (Fig. 7). This clearly shows that AOD concentration and spread were independent of the weather, variations in levels, sources, and lockdown.
Overall, gas fields showed the highest AOD levels across the whole country, which are usually located in northern part of Sindh province followed by the Kashmore power plant in northern Baluchistan and followed by the industrial areas of Sadiqabad with concentrations of $0.515 \mu \mathrm{g} / \mathrm{cm}^{2}$, $0.513 \mu \mathrm{g} / \mathrm{cm}^{2}$, and $0.41 \mu \mathrm{g} / \mathrm{cm}^{2}$, respectively. Out of megaand major cities of Pakistan, Multan city showed the highest levels of AOD $\left(0.357 \mu \mathrm{g} / \mathrm{cm}^{2}\right)$, followed by Hyderabad city and Sindh province $\left(0.353 \mu \mathrm{g} / \mathrm{cm}^{2}\right)$ being another major city of Pakistan. Interestingly, none of the top 3 cities of Pakistan showed the highest levels of AOD, i.e., Lahore, Islamabad, and Rawalpindi. Rather, Faisalabad showed the highest levels of AOD $\left(0.345 \mu \mathrm{g} / \mathrm{cm}^{2}\right)$ among major industrial cities. Previous studies have reported an increase in AOD from winter to summer (Gupta et al. 2013; Mansha 2011), although this temporal increase becomes noticeable only from the last quarter of April. Mansha et al., who analyzed $\mathrm{PM}_{2.5}$ concentrations in the industrial city of Karachi, 
Table 4 Summary of the changes observed in $\mathrm{NO}_{2}$ and AOD in 2019 and 2020 during lockdown

\begin{tabular}{|c|c|c|c|c|c|c|}
\hline \multirow[t]{2}{*}{ City/sector } & \multicolumn{3}{|c|}{$\mathrm{NO}_{2}\left(\mu \mathrm{mol} / \mathrm{m}^{2}\right)$} & \multicolumn{3}{|c|}{ AOD55 } \\
\hline & 2020 & 2019 & Change (\%) & 2020 & 2019 & Change (\%) \\
\hline \multicolumn{7}{|l|}{ Megacities } \\
\hline Karachi & 56.7 & 84.4 & -32.9 & 0.34 & 0.34 & 0.44 \\
\hline Lahore & 40.1 & 70.3 & -42.9 & 0.32 & 0.34 & -5.48 \\
\hline Faisalabad & 36.2 & 50.1 & -27.8 & 0.29 & 0.35 & -15.27 \\
\hline $\begin{array}{l}\text { Rawalpindi \& } \\
\text { Islamabad }\end{array}$ & 34.7 & 62.2 & -44.1 & 0.25 & 0.26 & -2.37 \\
\hline Average & 41.9 & 66.7 & -36.9 & 0.30 & 0.32 & -5.67 \\
\hline \multicolumn{7}{|l|}{ Major cities } \\
\hline Multan & 41.6 & 45.2 & -8.1 & 0.48 & 0.36 & 32.97 \\
\hline Peshawar & 32.8 & 41.7 & -21.2 & 0.26 & 0.23 & 13.93 \\
\hline Hyderabad & 35.1 & 46.6 & -24.7 & 0.42 & 0.35 & 18.62 \\
\hline Quetta & 14.6 & 24.6 & -40.6 & 0.21 & 0.22 & -4.17 \\
\hline Average) & 31 & 39.5 & -23.6 & 0.34 & 0.29 & 15.34 \\
\hline \multicolumn{7}{|l|}{ Industrial areas } \\
\hline Taxila & 37.7 & 54.8 & -31.2 & 0.24 & 0.28 & -13.13 \\
\hline Sadiqabad & 42.9 & 46.3 & -7.4 & 0.27 & 0.43 & -37.07 \\
\hline Average) & 40.3 & 50.6 & -19.3 & 0.26 & 0.35 & -25.10 \\
\hline \multicolumn{7}{|l|}{ Gas fields } \\
\hline Sui & 36.8 & 38.4 & -4.2 & 0.57 & 0.51 & -44.86 \\
\hline Daharki & 41.2 & 44.7 & -8 & 0.24 & 0.42 & -42.73 \\
\hline Ghotki & 42.2 & 48.1 & -12.3 & 0.52 & 0.52 & 0.62 \\
\hline Average & 40 & 43.7 & -8.2 & 0.44 & 0.48 & -28.99 \\
\hline \multicolumn{7}{|l|}{ Power plants } \\
\hline Kashmore & 38.3 & 65.7 & -41.7 & 0.45 & 0.41 & -45.19 \\
\hline Kotaddu & 30.2 & 52.4 & -42.4 & 0.37 & 0.37 & 0.69 \\
\hline Sahiwal & 39.8 & 62.2 & -36 & 0.26 & 0.34 & -24.17 \\
\hline Average & 36.1 & 60.1 & -40.1 & 0.36 & 0.37 & -22.89 \\
\hline \multicolumn{7}{|l|}{ Cement plants } \\
\hline Pezu & 48.6 & 42.1 & 15.6 & 0.41 & 0.41 & 0.71 \\
\hline Kalabagh & 51.5 & 39.4 & 30.7 & 0.32 & 0.39 & -17.96 \\
\hline Khewra & 28.7 & 34.3 & -16.3 & 0.35 & 0.36 & -2.31 \\
\hline Ameer & 29.1 & 35.1 & 5.1 & 0.28 & 0.30 & -6.91 \\
\hline Average & 39.5 & 37.7 & 8.8 & 0.34 & 0.37 & -6.62 \\
\hline
\end{tabular}

showed that industrial emissions contribute more than $50 \%$, followed by dust and secondary aerosols.

In April 2020, Pakistan had 81 power plants of different types (such as coal, RLNG, thermal, and nuclear) with a maximum installed capacity of $35,972 \mathrm{MW}$, compared to 33,452 MW in April 2019 (7.5\% growth). The largest share of energy is generated by thermal power plants. According to the 2020 economic survey of Pakistan, the share of thermal power dropped from 63\% in April 2019 to $58.4 \%$ in April 2020. In contrast, hydroelectric power increased from 25.8\% in April 2019 to 30.9\% in April 2020. Nuclear energy production increased from 3 to $8.2 \%$ during the same period, whereas renewable energy production decreased from 8.2 to $2.4 \%$. $\mathrm{NO}_{2}$ levels in megacities and major cities which depend on government energy regulations, economic stability, and its impact on energy consumption methods, regional pollution, and political stability and its impact on the energy sector, economic growth, and infrastructure development (Duncan et al. 2015). A rapid economic growth in several megacities has had a direct impact on $\mathrm{NO}_{2}$ concentrations. Duncan et al. (2015) reported an increase of $52 \%$ in Lahore and $46 \%$ in Islamabad between 2005 and 2014, whereas in Karachi, $\mathrm{NO}_{2}$ levels remained insignificant. Similar increases have been observed in many Asian countries (Duncan et al. 2015). Pollution transfer from neighboring countries may increase the amount of $\mathrm{NO}_{2}$ over a megacity even if proper regulations are in place, as observed in South Korea despite reduced local emissions, likely due to pollution transfer from China (Wei et al. 2019). 
Fig. 5. Tropospheric $\mathrm{NO}_{2}$ distribution over Pakistan during the three periods in 2018,2019 , and 2020
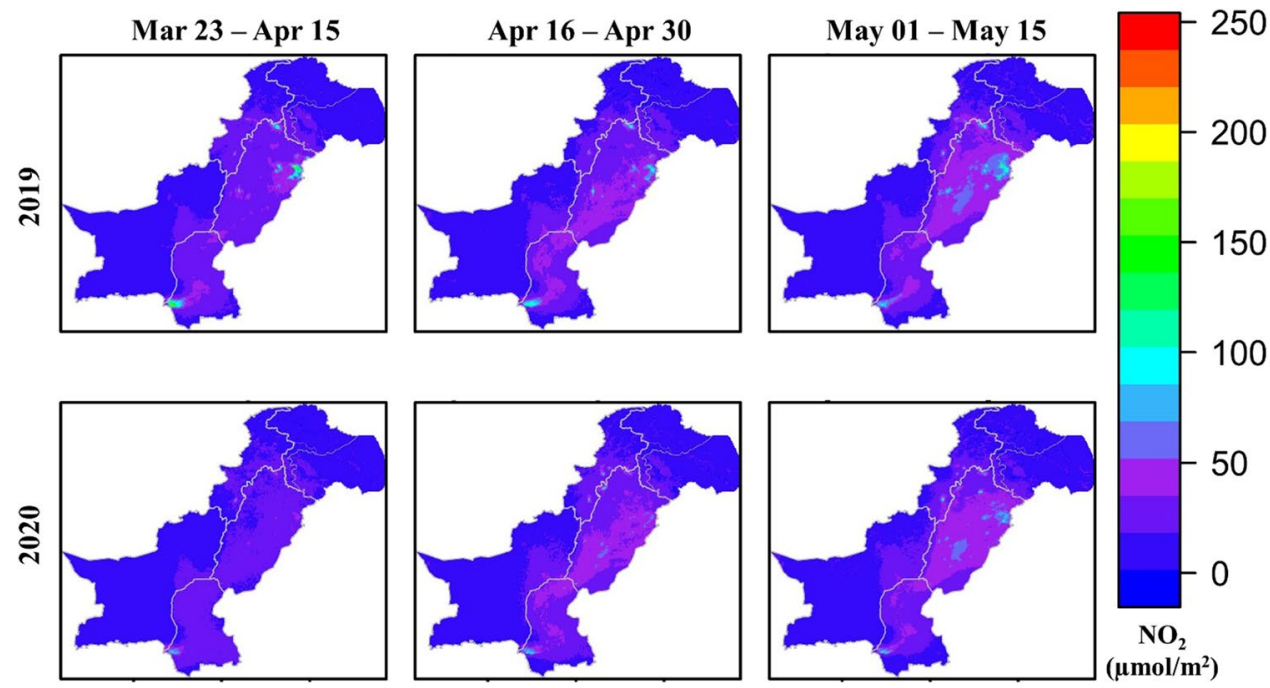
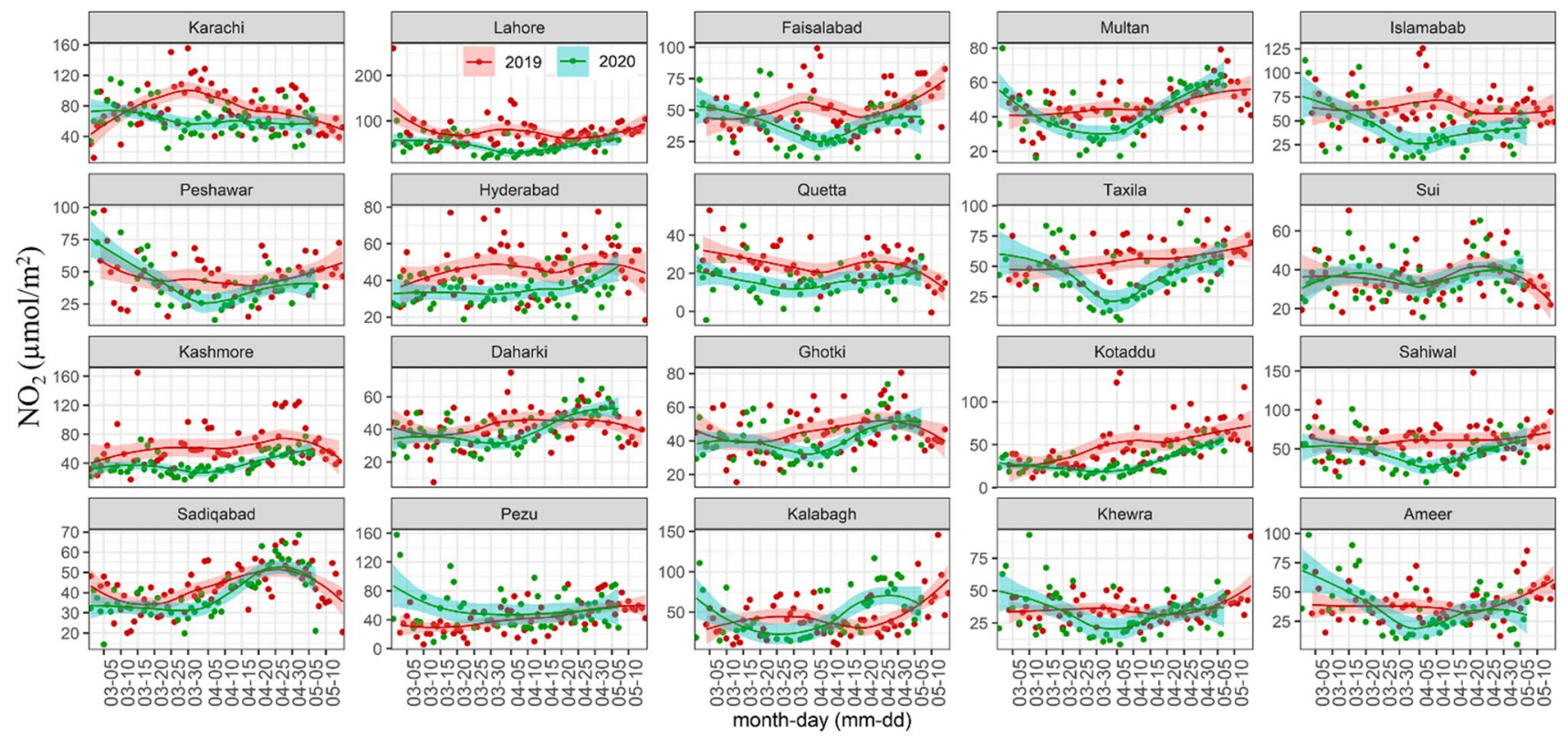

Fig. 6. Time series plots of tropospheric $\mathrm{NO}_{2}$ concentrations from March 1 to May 15 of 2019 and 2020 across various stages of the lockdown. The red and green circles indicate the $\mathrm{NO}_{2}$ values in 2019 and 2020, respectively. The lines indicate loess fitted curves, and the shaded colors around the lines show 95\% confidence intervals
Between 2007 and 2011, Pakistan's $\mathrm{NO}_{2}$ concentrations were above the limit of $40 \mu \mathrm{g} / \mathrm{m}^{3}$ recommended by the WHO (2020). The highest levels were recorded in major cities, such as Peshawar $\left(52 \pm 21 \mu \mathrm{g} / \mathrm{m}^{3}\right)$, Islamabad (49 $\left.\pm 28 \mu \mathrm{g} / \mathrm{m}^{3}\right)$, Lahore $\left(49 \pm 25 \mu \mathrm{g} / \mathrm{m}^{3}\right)$, and Karachi (46 $\left.\pm 15 \mu \mathrm{g} / \mathrm{m}^{3}\right)$, whereas the lowest levels were recorded in Quetta $\left(37 \pm 15 \mu \mathrm{g} / \mathrm{m}^{3}\right)$. The concentrations of other pollutants, such as $\mathrm{O}_{3}$ and $\mathrm{CO}$, were below the WHO limits.

\section{Energy, environment, and lockdown}

The total energy production of coal power plants has been decreasing globally since 2011 . In contrast, global net coalbased energy generation increased by $34.1 \mathrm{GW}$ from 2018 to 2019 , as $68.3 \mathrm{GW}$ capacity plants were installed, while $34.3 \mathrm{GW}$ capacity plants were decommissioned (Lu et al. 2021). China was the top contributor $(64.2 \% ; 43.5 \mathrm{GW})$ to 


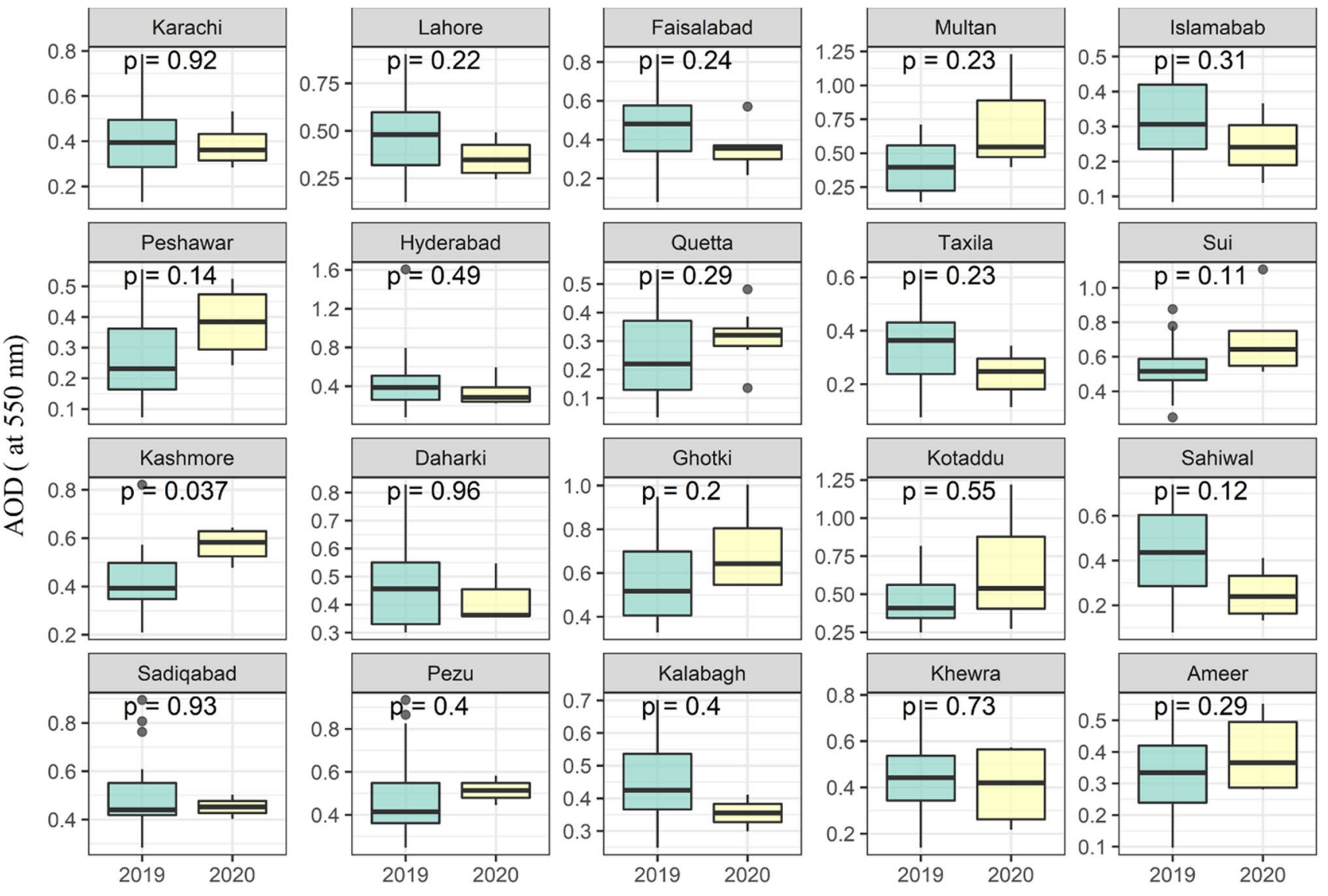

Fig. 7. Comparison of AOD during March 23 to April 15 of 2019 and 2020

the global increase in 2019 , followed by India $(12 \% ; 8.1$ $\mathrm{GW})$, Malaysia $(3.8 \% ; 2.6 \mathrm{GW})$, Indonesia $(3.5 \% ; 2.4 \mathrm{GW})$, and Pakistan $(3 \% ; 2 \mathrm{GW})$. Pakistan has ranked fifth in coalbased power generation since 2017. Its total installed capacity increased by $4.9 \mathrm{GW}$ from 2017 to 2019 , which accounts for $2.7 \%$ of the global power generation from coal during that period, below Vietnam $(2.68 \%$; $5.1 \mathrm{GW})$, South Korea (3\%; $5.5 \mathrm{GW})$, India $(13.9 \% ; 25.4 \mathrm{GW})$, and China (61.1\%; $111.8 \mathrm{GW})$. Currently, its total installed capacity from nine operating coal-fired power plants is 5.09 GW (GEM 2020). The share of coal in electricity generation fell by 1.5 percentage points to $36.4 \%$ in 2019 compared to previous years, globally. Coal consumption fell by $0.6 \%$, while its share in the energy mix fell to $27 \%$. China's coal consumption share is $51.7 \%$, India's share is $11.8 \%$, and that of the USA is $7.2 \%$.

Several lessons can be learned from our analysis of the pre-lockdown and during/after lockdown periods. One is that heavy reliance on fossil fuels with limited production capacity cannot be sustained for long periods. Pakistan must invest in renewable energy and diversify its energy mix to achieve "Sustainable Development Goal 11 (Sustainable Cities and Communities)" (Klemeš et al. 2020). Otherwise, an energy crisis can easily be foreseen. Before the lockdown, energy generation exhibited a clear pattern of high (usually in winter and spring) and low production periods (usually in the monsoon and summer seasons). This pattern can be observed in all three major power plants in Pakistan. $\mathrm{NO}_{2}$ emissions are related to energy production, although rainfall reduces $\mathrm{NO}_{2}$ concentrations during the monsoon season. A significant reduction in emissions was observed during the lockdown of 2020. Post-lockdown scenario lessons were shown to reduce the use of fossil fuels not only in the industrial sector but also in transportation and urban centers. $\mathrm{NO}_{2}$ emissions from a single power plant are equivalent to the emissions from a major city, which is alarming. Most cities of Pakistan showed high emissions before and low emissions during the lockdown. It can be concluded that there is a direct and visible nexus between energy, the environment, and COVID-19 in the case of Pakistan. Proper energy regulation can greatly reduce $\mathrm{NO}_{2}$ concentrations, as observed in Chinese cities such as Guangzhou, Shenzhen, Beijing, and the Pearl River Delta region. Significant increases have been observed in the northern region of China (Jin and Holloway 2015). 


\section{Conclusion and policy implications}

This study conducted a satellite remote sensing-based assessment of $\mathrm{NO}_{2}$ emissions and AOD associated with energy production and consumption and the COVID-19 lockdown restrictions in Pakistan, as well as a comparison between the periods before and during/after the lockdown. The results indicate that a substantial decrease in energy consumption led to a considerable decrease in emissions, albeit to erratic degrees allover various sources of emission. Coal power plants showed the highest $\mathrm{NO}_{2}$ concentrations followed by megacities and major cities, whereas industrial and transportation sectors remained the key contributor in the cities. Likewise, AOD concentrations were highly unpredictable and showed various changes in various parts of the study areas. For instance, gas fields and thermal power plants of Sindh and Baluchistan province were at the top along with Sadiqabad industrial areas. Only increase in AOD was observed in major cities of Pakistan. Methods used in this study and findings as well as providing a basis for measuring the contributions to pollution of numerous sources in case of ground-based monitoring systems are missing. Furthermore, we excluded the rainfall factor during the monsoon season to quantify the changes in $\mathrm{NO}_{2}$ emissions and AOD. Interestingly, we found that rainfall contributes to a reduction in $\mathrm{NO}_{2}$ emissions but is not significantly associated with AOD. The unprecedented disruption of human activities due to the lockdown gave us an invaluable opportunity to measure the contributions of different emission sources to air pollution in Pakistan. Our findings highlight the need for appropriate management of transportation systems, land use expansion, use of renewable energy, and industrial emissions to tackle the urban surface energy balance. Future research could evaluate the environmental cost of energy production and consumption across various sectors in Pakistan to recommend appropriate environmental policies for sustainable development. The observed reduction in $\mathrm{NO}_{2}$ emissions in Pakistan during the lockdown indicates that the major contribution comes from energy consumption, as most power plants did not cease operations. Hence, for Pakistan, the major challenges to achieving SGDs lie in development and urbanization and not in power production. Moreover, inclusion of renewable energy infrastructure into energy mix of Pakistan using bottom-up approach may work effectively. Use of renewable energy such as solar panels and biogas plants at household level will also reduce dependency on the government.

Data availability The datasets used and/or analyzed during the current study are available from the corresponding author on reasonable request.
Author contribution Sawaid Abbas, conceptualization, analysis, and editing. Ghaffar Ali, writing - review and editing. Faisal Mueen Qamer, research design and analysis. Syed Muhammad Irteza, quality and validation.

\section{Declarations}

Ethics approval and consent to participate Not applicable

Consent for publication Not applicable

Conflict of interest The authors declare no competing interests.

\section{References}

Ali G, Abbas S, Qamer FM, Irteza SM et al (2021a) Environmental impacts of shifts in energy, emissions, and urban heat island during the COVID-19 lockdown across Pakistan. J Cleaner Product 291:125806

Ali G, Abbas S, Qamer FM, Irteza SM (2021b) Environmental spatial heterogeneity of the impacts of COVI-19 on the top-20 metropolitan cities of Asia-Pacific. Nat Scientific Reports 11:20339

Anwar J (2016) Analysis of energy security, environmental emission and fuel import costs under energy import reduction targets: a case of Pakistan. Renew Sustain Energy Rev 65:1065-1078

Asian Development Bank (2020) The economic impact of the COVID19 outbreak on developing Asia. Asian Dev Bank 9:1-14 Available at https://doi.org/10.22617/BRF200096 (assessed on 01-12-2020)

Bao R, Zhang A (2020) Does lockdown reduce air pollution? Evidence from 44 cities in northern China. Sci Total Environ 731(1954):139052

Bhutto AW, Bazmi AA, Zahedi G (2013) Greener energy: issues and challenges for Pakistan - wind power prospective. Renew Sustain Energy Rev 20:519-538

Broomandi P, Karaca F, Nikfal A, Jahanbakhshi A, Tamjid M, and Kim JR (2020) Impact of COVID-19 event on the air quality in Iran aerosol and air quality research 20(8): 1793-1804

Colbeck I, Nasir ZA, Ali Z (2010) The state of ambient air quality in Pakistan-a review. Environ Sci Pollut Res 17:49-63

Dantas G, Siciliano B, Boscaro B, Cleyton M, Arbilla G (2020) The impact of COVID-19 partial lockdown on the air quality of the city of Rio de Janeiro, Brazil. Sci Total Environ 729:139085

Duncan BN, Lamsal LN, Thompson AM, Yoshida Y, Lu Z, Streets DG, Pickering KE (2015) J Geophys Res Atmospheres 121(2):976-996

Filonchyk M, Hurynovich V, Yan H, Gusev A, Shpilevskaya N (2020) Impact assessment of COVID-19 on variations of SO2, NO2, CO and AOD over East China. Aerosol Air Qual Res 20(7):1530-1540

Gautam S (2020) The influence of COVID-19 on air quality in India : a boon or inutile. Bull Environ Contamination Toxicol 104(6):724-726

GEM (2020) Global Enery Monitoring. Building an open guide to the world's energy system. Available at: https://globalenergymonitor. org/(accessed on January 2021)

Gupta P, Khan MN, da Silva A, Patadia F (2013) MODIS aerosol optical depth observations over urban areas in Pakistan: quantity and quality of the data for air quality monitoring. Atmos Pollut Res 4:43-52

HDIP (2019) Statistical Year Book 2019. Hydrocarbon Development Institute of Pakistan. Ministry of Energy (Petroleum Division), Government of Pakistan, Islamabad 
Isaifan RJ (2020) The dramatic impact of Coronavirus outbreak on air quality: has it saved as much as it has killed so far? Glob J Environ Sci Manag 6:275-288

Jin X, Holloway T (2015) Spatial and temporal variability of ozone sensitivity over China observed from the ozone monitoring instrument. J Geophys Res Atmospheres 120(14):7229-7246

Klemeš JJ, Fan YV, Jiang P (2020) The energy and environmental footprints of COVID-19 fighting measures - PPE, disinfection, supply chains. Energy 15(211):118701

Kumar N, Chu A, Foster A (2007) An empirical relationship between $\operatorname{PM}(2.5)$ and aerosol optical depth in Delhi Metropolitan. Atmospheric Environ 41(21):4492-4503

Levy RC, Remer LA, Kleidman RG, Mattoo S, Ichoku C, Kahn R, Eck TF (2010) Global evaluation of the Collection 5 MODIS dark-target aerosol products over land. Atmos Chem Phys 10:10399-10420

Lu H, Ma X, Ma M (2021) A hybrid multi-objective optimizerbased model for daily electricity demand prediction considering COVID-19. Energy 219:119568

Mahato S, Pal S, Ghosh KG (2020) Effect of lockdown amid COVID19 pandemic on air quality of the megacity Delhi, India. Sci Total Environ 730:139086

Maliszewska M, Mattoo A, Mensbrgghe D (2020) The potential impact of COVID-19 on GDP and trade a preliminary assessment (English), Policy Research Working Paper; no. WPS 9211; COVID-19 (Coronavirus), Washington, D.C

Mansha M (2011) Assessment of fine particulate matter $\left(\mathrm{PM}_{2.5}\right)$ in metropolitan Karachi through satellite and ground-based measurements. J Appl Remote Sens 5:053546

Mirjat N, Uqaili M, Harijan K, Valasai G, Shaikh F, Waris M (2017) A review of energy and power planning and policies of Pakistan. Renew Sustain Energy Rev 79:110-127

Myllyvirta L (2020) Quantifying the economic costs of air pollution from fossil fuels key messages. Available at: https://energyandc leanair.org/publications/costs-of-air-pollution-from-fossil-fuels/ (assessed on 10-11-2021)

Otmani A, Benchrif A, Tahri M, Bounakhla M, Mahjoub E, El M, Krombi M (2020) Impact of Covid-19 lockdown on PM 10, SO2 and NO2 concentrations in Salé City (Morocco) in Salé city. Sci Total Environ 735(2):139541

Omrani H, Omrani B, Parmentier B, Helbich M (2020) Spatio-temporal data on the air pollutant nitrogen dioxide derived from Sentinel satellite for France. Data Br 28:105089

Rauf O, Wang S, Yuan P, Tan J (2015) An overview of energy status and development in Pakistan. Renew Sustain Energy Rev 48:892-931

Rowland J, Harrison L, Hoell A et al (2015) The climate hazards infrared precipitation with stations - a new environmental record for monitoring extremes. Sci. Data 2:1-21
Sami M, Waseem A, Akbar S (2006) Quantitative estimation of dust fall and smoke particles in Quetta Valley. J Zhejiang Univ Sci B 7:542-547

Sánchez-Triana E, Enriquez S, Afzal J, Nakagawa A, Khan AS (2014) Cleaning Pakistan's air: policy options to address the cost of outdoor air pollution. The World Bank

SBP (2018) Annual Report 2017-2018 - the state of Pakistan's economy, Islamabad, Pakistan

Shahid MZ, Hong L, Yu-lu QIU, Shahid I (2015) Source sector contributions to aerosol levels in Pakistan. Atmos Ocean Sci Lett 8:308-313

Shahzada M, Nawaz N, Alvi S (2018) Energy security for socioeconomic and environmental sustainability in Pakistan. Heliyon 4(10):e00854

Sharma S, Zhang M, Gao J, Zhang H, Harsha S (2020) Effect of restricted emissions during COVID-19 on air quality in India. Sci Total Environ 728:138878

Stirnberg R, Cermak J, Anderse H (2018) An Analysis of factors influencing the relationship between satellite-derived AOD and ground-level PM10. Remote Sens 10(9):1353

Tobías A, Carnerero C, Reche C, Massagué J, Via M, Minguillón MC, Querol X (2020) Changes in air quality during the lockdown in Barcelona ( Spain ) one month into the SARS-CoV-2 epidemic. Sci Total Environ 726:138540

Wei J, Peng Y, Guo J, Sun L (2019) Performance of MODIS Collection 6.1 Level 3 aerosol products in spatial-temporal variations over land. Atmos Environ 206:30-44

WHO (2020) Coronavirus disease COVID-19 pandemic. Available at: https://www.who.int/emergencies/diseases/novel-coronavirus2019 (assessed on 25 May, 2020)

World Bank (1998) Thermal power: guidelines for new plants. Pollution Prevention and Abatement Handbook, World Bank Group

Yuri L, Nakada K, Custodio R (2020) Novel coronavirus information center. Elsevier's free health and medical research on the novel coronavirus (SARS-CoV-2) and COVID-19. Available at: https://www.elsevier.com/connect/coronavirus-information-center (Accesed on January 2021).

Zhao Y, Zhang J, Wang Z (2020) Cost analysis of environmental protection price of coal-fired plants in China. Environ Sci Pollut Res Int 27(15):18729-18742

Publisher's note Springer Nature remains neutral with regard to jurisdictional claims in published maps and institutional affiliations. 